\title{
METHODS FOR THE REDUCTION OF CO EMISSIONS IN THE CEMENT INDUSTRY
}

\author{
Jerzy Duda, Mariusz Kolosowski \& Jacek Tomasiak
}
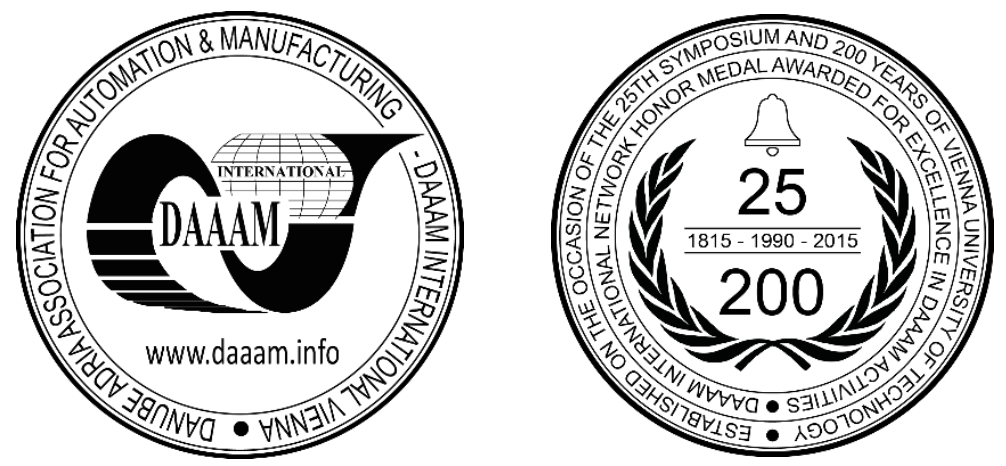

This Publication has to be referred as: Duda, J[erzy]; Kolosowski, M[ariusz] \& Tomasiak, J[acek] (2016). Methods for the Reduction of CO2 Emissions in the Cement Industry, Proceedings of the 27th DAAAM International Symposium, pp.0122-0130, B. Katalinic (Ed.), Published by DAAAM International, ISBN 978-3-902734-08-2, ISSN 1726-9679, Vienna, Austria

DOI: $10.2507 / 27$ th.daaam.proceedings.018

\begin{abstract}
Cement burning process of high temperature is counted among industries particularly disruptive for the environment. This is especially true of carbon dioxide emissions, which is the sum of emissions from the combustion of fuel and emissions resulting from the technological process. The issue of carbon dioxide emissions reduction has been presented on the example of cement industry. Existing activities in this area resolve mainly to the reduction of heat consumption in the process of clinker burning and limiting its content in cement. Those activities have almost completely exhausted the possibility of further $\mathrm{CO} 2$ reduction. New, even greater reductions, which the European Commission plans to implement after 2020, require a different approach to this problem. The authors conduct research on possibilities of the reduction of greenhouse gases emission in the cement industry, among others through the use of the ORC (the organic Rankine cycle) and CCS (carbon capture and storage) technologies.
\end{abstract}

Keywords: cement production; rotary kiln; greenhouse gases; waste; ORC.

\section{Introduction}

Despite the significant reduction in the energy intensity of production process and various measures being implemented to reduce the emissions of greenhouse gases (GHGs), recent years witnessed a progressive growth of atmospheric $\mathrm{CO}_{2}$ concentrations and the resulting increase of temperatures on Earth. According to the forecasts by the International Energy Agency, the civilizational and economic growth will cause continued increase in the consumption of electricity, with non-renewable (fossil) fuels having a significant share (ca. 80\%) in the production thereof. As a consequence, the greenhouse gas emissions will increase leading to adverse climate changes. The changes are presented in the Fig. 1. 

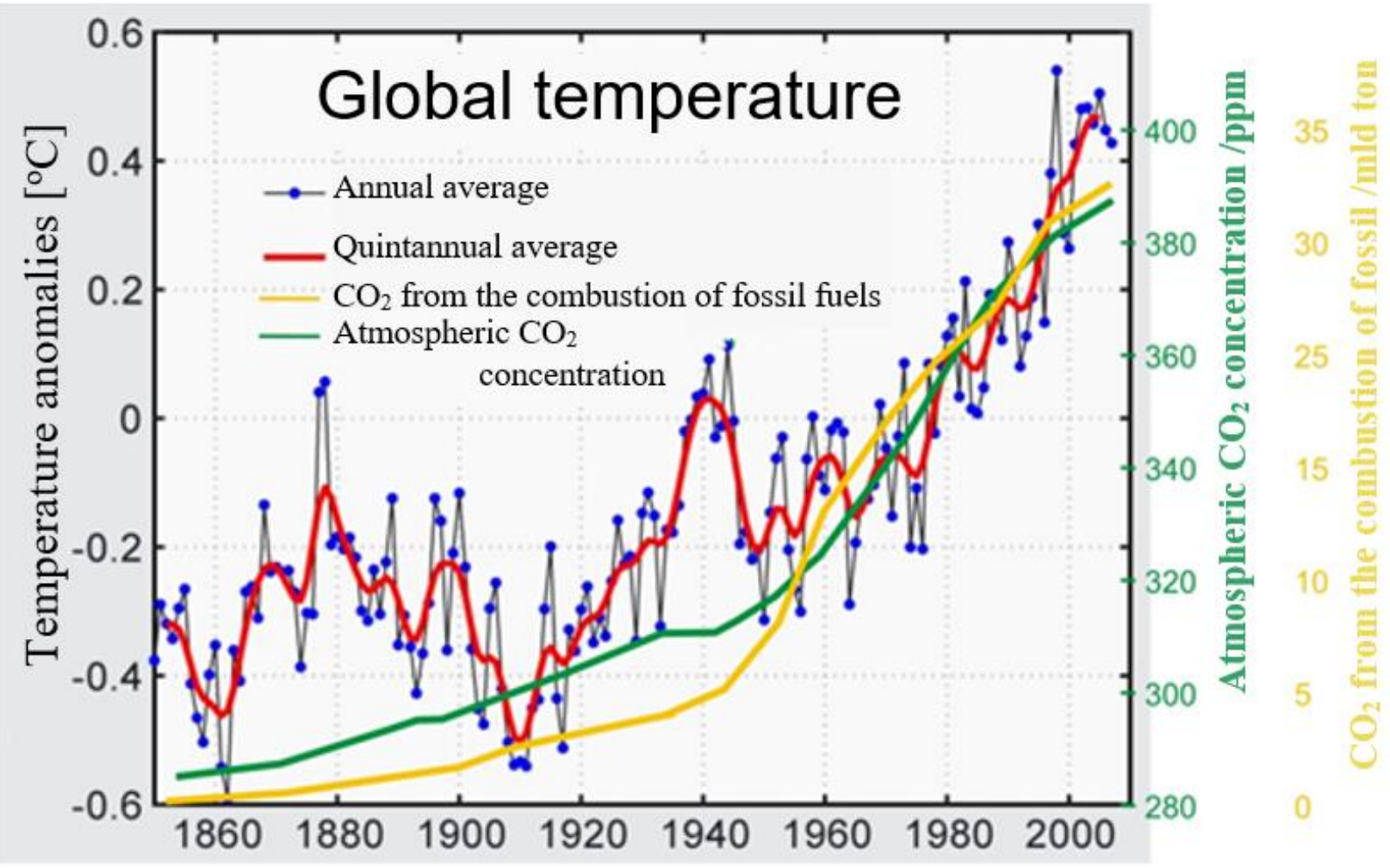

Fig. 1. Changes in Earth temperatures [1] and atmospheric $\mathrm{CO}_{2}$ levels

The research conducted by the Intergovernmental Panel on Climate Change demonstrated that atmospheric concentration of carbon dioxide increased by 1.5 to $3 \mathrm{ppm}$ each year starting from mid-19 $9^{\text {th }}$ century to reach ca. $380 \mathrm{ppm}$ in the baseline year (2005). Already in 1992, the United Nations Framework Convention on Climate Change (UNFCCC) was adopted during the "Earth Summit" Conference in Rio de Janeiro, with basic objective to "achieve (...) stabilization of greenhouse gas concentrations in the atmosphere at a level that would prevent dangerous anthropogenic interference with the climate system". Consequently, an international agreement, referred to as the Kyoto Protocol, was developed in 1997 with the aim to reduce anthropogenic emissions of greenhouse gases (as expressed in carbon dioxide equivalents) in the reference period of 2008-2012 in signatory countries. Considering the above, the countermeasures for climate changes were considered one of the priorities of the new energy policy of the European Union. The target scenario of the European Commission assumed that the Earth temperature increase would be restricted to $2^{\circ} \mathrm{C}$. According to expert opinions, a condition to meet this restriction would be to reduce the worldwide emissions of $\mathrm{CO}_{2}$ by $50 \%$ as compared to 2005. Such a great reduction in carbon dioxide emissions requires a drastic reduction in the use of fossil fuels and increase in the use of renewable energy sources (RES). This is particularly difficult to achieve in Poland where coal is the main industrial fuel due to its cost and availability. Similar to the energy production sector, the cement industry consumes significant quantities of coal. Therefore, the quest to reduce the energy intensity and thus the production costs as well as to reduce the harmful environmental impact of cement is still valid.

According to the Integrated Pollution Prevention Control (IPCC) directive, acceptable emission levels should be determined on the basis of BREFs (BAT Reference Documents, i.e. reference documents for best available techniques not causing excessive increase in costs and preventing or reducing air pollution). The technological changes in worldwide industry resulting from the strive to reduce energy intensities and to meet the BREF-defined environmental protection standards pertain mainly to energy intensive processes such as cement clinker sintering technologies and raw material and cement milling techniques [2,3]. Recent years witnessed a significant development of novel cement production technologies which were successfully implemented during modernization of the cement industry in Poland. The Fig. 2. presents the impact of the modernization of the cement industry in Poland on the energy consumption and ecological parameters. 


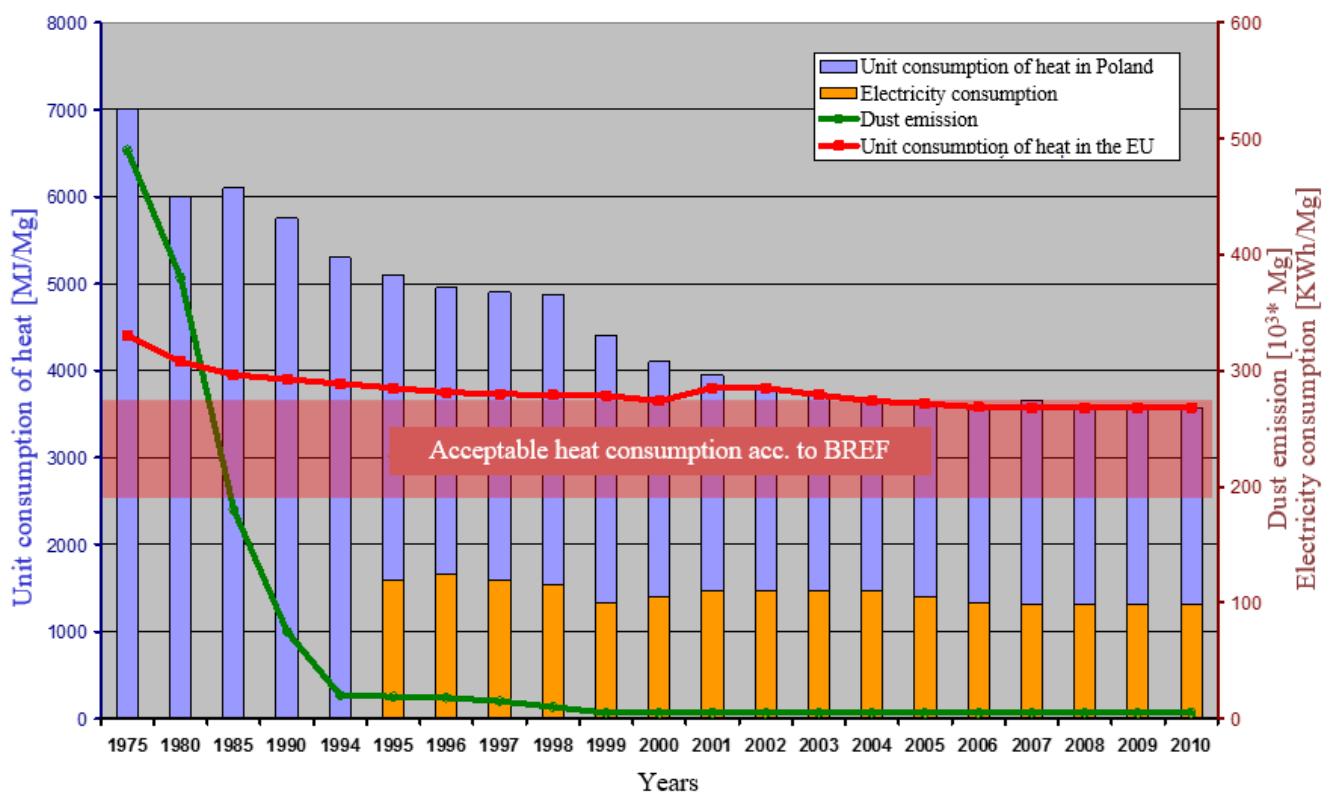

Fig. 2. The impact of the modernization of the cement industry on energy intensity and dust emissions

As shown by the presented data, implementation of innovative technologies in Polish cement industry led to a significant (50\%) reduction in energy intensity and dust emissions. To all purposes, our industry meets the BAT standards and is one of the best cement industries in Europe. The problem currently faced by the cement industry and requiring a quick solution consists in the reduction of greenhouse gas emissions, particularly due to the announced new, significantly lower limits of acceptable emissions to be implemented in the future.

\section{Cement production vs. $\mathrm{CO}_{2}$ emission}

As part of the UNFCCC (Kyoto Protocol of 1997), Poland has committed itself to reduce the emissions of GHGs by $6 \%$ as compared to the level of 1988 (the baseline year). The cement industry in Poland, which had undergone a radical modernization in years 1990-2000, had virtually no problems with meeting the new limits. The first problems occurred when the European Commission, having considered the positive changes resulting from the restructuring of Polish industry (and the generated $\mathrm{CO}_{2}$ emission reserves), made a decision to reduce the limits for Poland in 2005. In recent years, a progressive increase in restrictions on acceptable GHG emissions can be observed. Whereas the requirement to reduce the acceptable $\mathrm{CO}_{2}$ emission by $20 \%$ until 2020 (according to the $3 \times 20$ climate initiative) can be achieved, the expected further reductions to be entered in force after 2020 pose a problem for the cement industry in Poland. In light of the novel assumptions regarding the restrictions in $\mathrm{CO}_{2}$ emissions after 2020, published by the European Commission in the Green Book in 2013, novel aims are set to be achieved by 2030, including:

- $\mathrm{CO}_{2}$ emission being reduced by $40 \%$,

- RES contribution to reach $27 \%$ of overall energy production.

The assumed new acceptable emission limit is particularly unfavorable for the cement industry where the main part of emissions does not originate from combustion; instead, emissions are generated in the technological process of the decarbonation of limestones used as the main raw material in the production of cement clinker. The compliance with further restrictions of GHG emissions expected after 2020 will require novel, innovative techniques and technologies of cement production.

Similar to the production of electricity, the cement production process is characterized by high emission of carbon dioxide being not only the result of fuel (carbon) combustion processes. The main part of $\mathrm{CO}_{2}$ emissions in cement production processes originate from decarbonation of calcium and magnesium carbonates being the basic components of kiln feed. Decarbonation proceeds in line with the following equations:

$$
\begin{aligned}
& \mathrm{CaCO}_{3}+\mathrm{Q}=\mathrm{CaO}+\mathrm{CO}_{2} \uparrow \\
& \mathrm{MgCO}_{3}+\mathrm{Q}=\mathrm{MgO}+\mathrm{CO}_{2} \uparrow
\end{aligned}
$$

Carbon dioxide present in the rotary kiln waste gas originates from the combustion of fuel (fuel-related $\mathrm{CO}_{2}^{P}$ ) and from the decomposition of carbonates (material-related $\mathrm{CO}_{2}^{S}$ ):

$\sum \mathrm{CO}_{2}=\mathrm{CO}_{2}^{P}+\mathrm{CO}_{2}^{S}$ 
The production of $1 \mathrm{~kg}$ of cement clinker (the main component of cement) in the rotary kiln emits ca. $0.86 \mathrm{~kg}$ of $\mathrm{CO}_{2}$ . Of these $0.56 \mathrm{~kg}$ of $\mathrm{CO}_{2}$ (ca. $60 \%$ ) is ascribed to emission resulting from decarbonation of the kiln feed whereas the remaining $0.3 \mathrm{~kg}$ of $\mathrm{CO}_{2}$ results from the combustion of fuel in the clinker sintering process.

The extent of fuel-related emission $\left(\mathrm{CO}_{2}^{P}\right.$ ) depends on the type of fuel and energy intensity of the clinker sintering process, whereas the extent of material-related emission $\left(\mathrm{CO}_{2}^{S}\right)$ depends on the chemical composition of material feed (carbonate and non-carbonate carbon content). The Table 1 presents the emissions of carbon dioxide depending on the clinker sintering technology in use.

\begin{tabular}{|l|l|l|l|l|}
\hline Quantity & Unit & $\begin{array}{l}\text { Dry } \\
\text { method }^{1}\end{array}$ & $\begin{array}{l}\text { Dry } \\
\text { method }^{2}\end{array}$ & $\begin{array}{l}\text { Wet } \\
\text { method }\end{array}$ \\
\hline Heat consumption & $\mathrm{GJ} / \mathrm{Mg} \mathrm{cl}$ & 3.4 & 4.2 & 6.8 \\
\hline Fuel-related emission benchmark & $\mathrm{kg} \mathrm{CO}_{2} / \mathrm{GJ}$ & 94.5 & 94.5 & 94.5 \\
\hline Fuel-related emission & $\mathrm{kg} \mathrm{CO}_{2} / \mathrm{Mg} \mathrm{cl}$. & 321 & 397 & 643 \\
\hline Raw material-related emission* & $\mathrm{kg} \mathrm{CO}_{2} / \mathrm{Mg} \mathrm{cl}$. & 535 & 535 & 535 \\
\hline Total emission & $\mathrm{kg} \mathrm{CO}_{2} / \mathrm{Mg} \mathrm{cl}$. & $\mathbf{8 5 6}$ & $\mathbf{9 3 2}$ & $\mathbf{1 1 7 8}$ \\
\hline
\end{tabular}

* Fuel- and raw material-related rates as used for the first level of accuracy in $\mathrm{CO}_{2}$ emission monitoring [4],

${ }^{1}$ short kiln with four-stage cyclone heat exchanger;

2 long dry method kiln.

Table 1. The impact of the clinker sintering method on $\mathrm{CO}_{2}$ unit emission rates

As shown by the presented data, emission is largely dependent on the sintering technology and its energy intensity (unit heat consumption). As the result of recent modernization of the cement industry in Poland, consisting mainly in the elimination of the energy-intensive wet method and implementation of novel, dry sintering methods in kilns with multistage cyclone heat exchangers and preliminary calcination systems. The modernization brought about a significant reduction in $\mathrm{CO}_{2}^{P}$ emission from fuel combustion processes (ca. $300 \mathrm{~kg} \mathrm{CO}_{2} / \mathrm{Mg}$ cl.).

Currently, when virtually all technological possibilities to reduce the energy intensity were used up, the search is ongoing for alternative ways to further reduce the emission of carbon dioxide.

\section{The impact of waste fuels and materials on the reduction of $\mathrm{CO}_{2}$ emission}

The deficit in natural raw materials due to the mass production of cement combined with the high costs of fuels and the requirements to reduce the emission of greenhouse gases are the driving forces behind the industry's search for novel technologies for utilization of waste fuels and materials. The Fig. 3 presents the possible uses of waste fuels and materials in cement production processes.

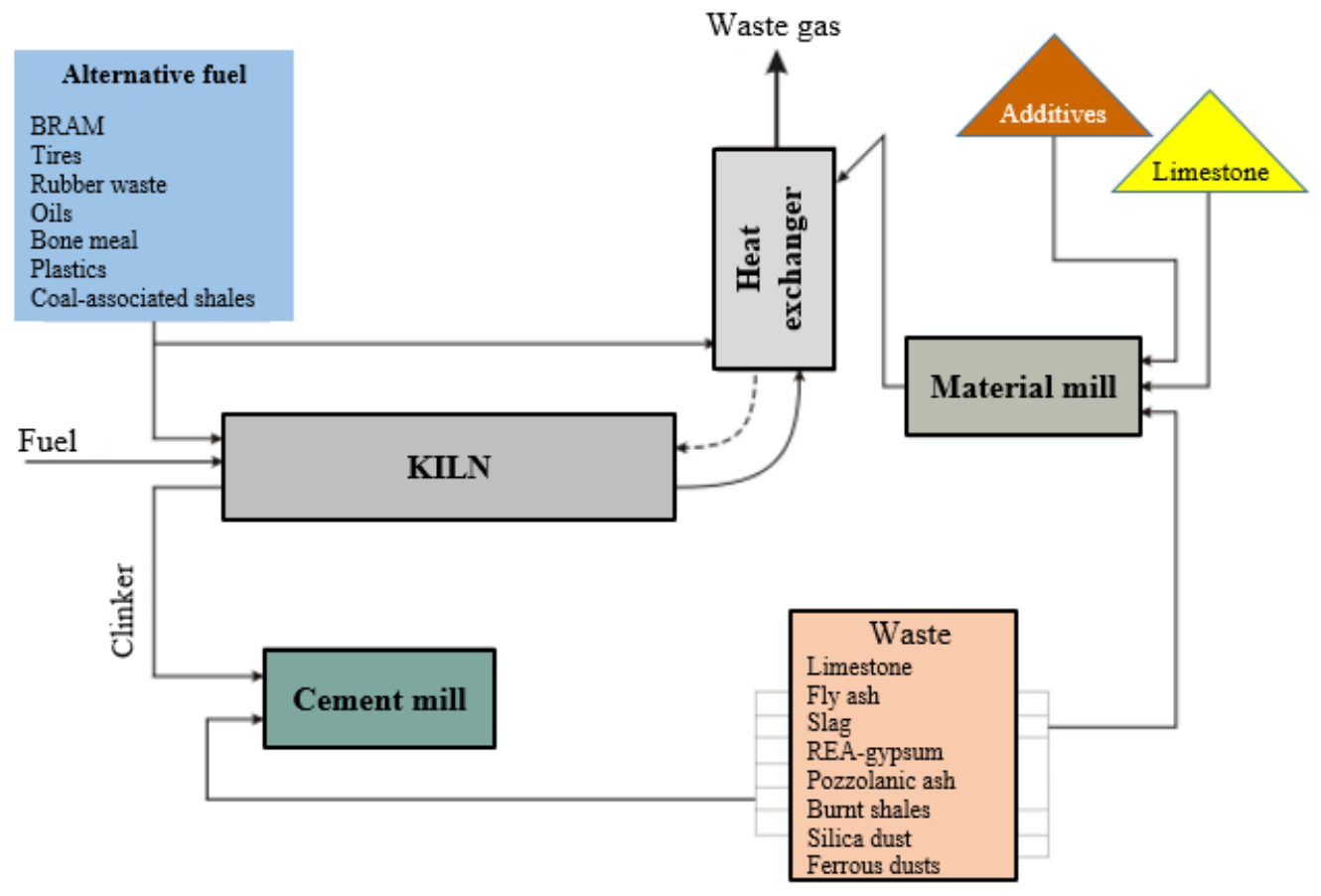

Fig. 3. Possible uses of waste fuels and materials in cement production 
A large part of waste materials such as fly ash from power plants, blast-furnace slag, silica dust or gypsum from flue gas desulphurization plants are already commonly used in cement mills. Similarly, utilization of waste fuels are common. Novel technologies of cement sintering in kilns featuring cyclone heat exchangers and preliminary decarbonation systems (precalcinators) facilitate combustion of various types of low-calorific fuels or combustible waste [4]. The temperature conditions within rotary kilns as well as the possibility to load alternative fuel into different sections of the kiln (as shown in the Fig. 3) facilitate the use of fuels of various physical forms (liquids, chunks, and dusts) [5].

The major issue in thermal utilization of waste material consists in the emission of hazardous gases - polychlorinated dibenzodioxins and dibenzofurans (PCDD and PCDF). Due to high temperatures of gas streams $\left(>2000^{\circ} \mathrm{C}\right)$ and the sintered materials (ca. $1430^{\circ} \mathrm{C}$ ) as well as to the turbulences and flow times within the high temperature zone $\left(>1100^{\circ} \mathrm{C}\right)$ co-combustion of alternative fuels with carbon dust in rotary cement kilns meet all the requirements of the Ordination of the Minister of Economy dated 21 March 2002 on the conditions of thermal waste transformation processes (Journal of Laws 2002.37.339). As seen from the data presented in the diagram of a typical modern rotary kiln (Fig. 4), gases dwell in the kiln at temperatures of $>1100^{\circ} \mathrm{C}$ over a period of ca. $7 \mathrm{~s}$ which secures the requirements associated with the destruction of toxic PCDD and PCDF compounds.

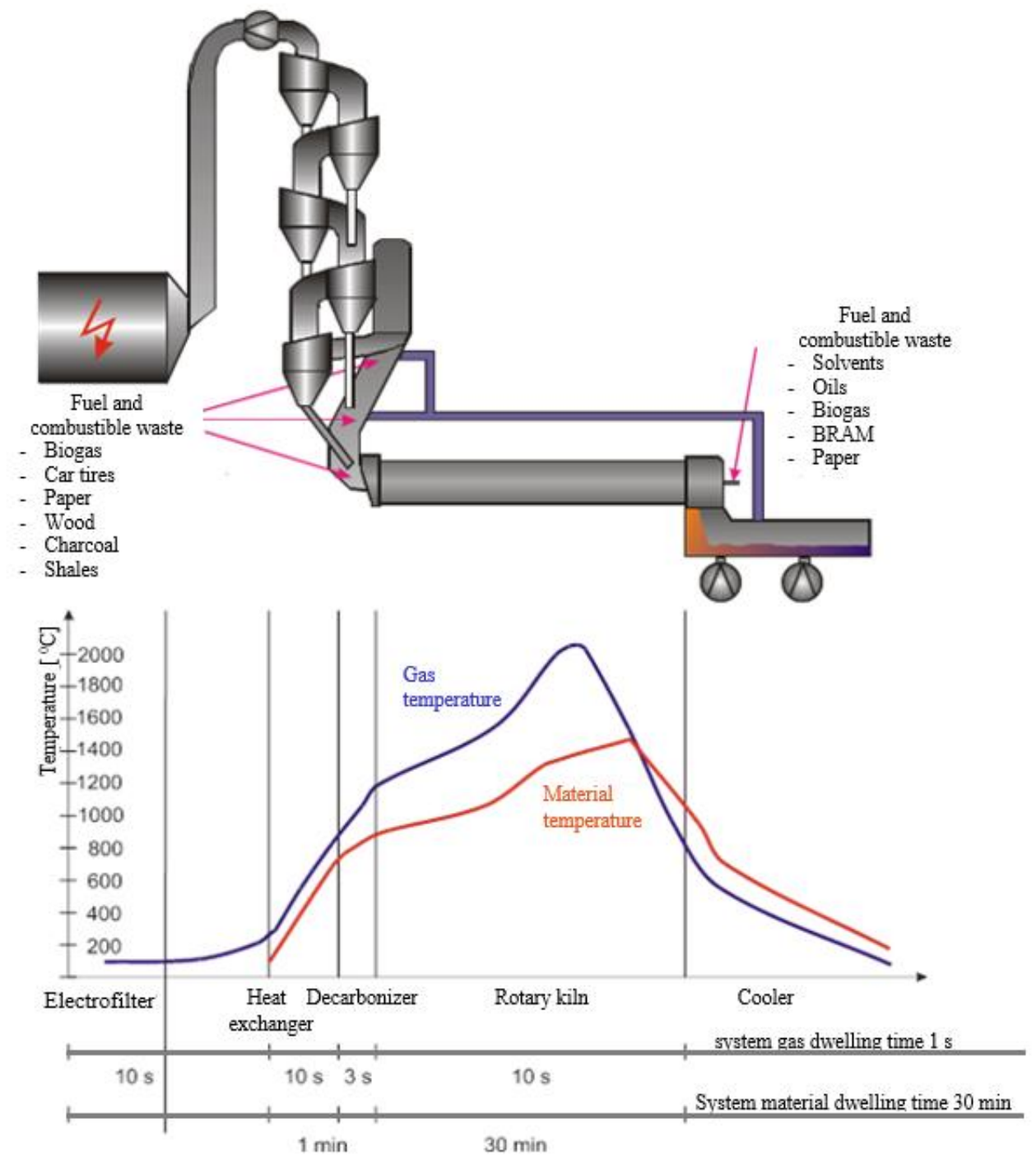

Fig. 4. A diagram of the rotary kiln with distribution of gas and sintered material temperatures

The use of waste fuels as substitutes for natural fuels (carbon) in the cement production process is in line with the principles of sustained growth and the objectives of the $3 \times 20$ climate initiative. Besides the reduction in the consumption of non-renewable (fossil) fuels, an important effect of the use of waste fuels consists in the reduction of the emission of hazardous gases $\left(\mathrm{CO}_{2}\right.$ and $\left.\mathrm{NO}_{\mathrm{x}}\right)$. The reduction in the emission of carbon dioxide stems from the reduced consumption of hard coal which is characterized by high benchmark value (ca.95 $\mathrm{kg} \mathrm{CO}_{2} / \mathrm{GJ}$ ) as compared to the emission from the combustion of alternative-derived fuels, commonly containing biomass with a significantly lower benchmark value (ca.55 $\mathrm{kg} \mathrm{CO} / \mathrm{GJ}$ ). Thus, $\mathrm{CO}_{2}$ emission may be reduced by ca. $40 \mathrm{~kg} \mathrm{CO}_{2} / \mathrm{GJ}$ compared to hard coal combustion. Waste utilization is an important ecological effect of the use of alternative-derived fuels. Compared to other methods of thermal 
utilization, rotary cement kilns feature a number of advantages that ensure waste-free, environmentally safe combustion of alternative fuels and thus the combustion of waste fuels in rotary cement kilns is increasingly considered to be one of pro-ecological means for utilization of hazardous waste materials [6]. Despite the significant percentage share (ca. 40\%) of alternative fuels in the clinker sintering process and the resulting environmental benefits, these measures are insufficient to achieve the required levels of $\mathrm{CO}_{2}$ emissions (reduction by 20\%). This shows that no further reduction in $\mathrm{CO}_{2}$ emission is possible for the conventional clinker sintering technology. The remaining possibility to reduce the emissions from the sintering process consists in modification of the phase composition of clinker (alite reduction). The energy-related effects of this modification include the reduction in the temperature and energy intensity of the clinker production process. However, the applicability of this modification are limited due to the required properties of the cement product. A new method for reducing hazardous gas $\left(\mathrm{CO}_{2}\right.$ and $\left.\mathrm{NO}_{\mathrm{x}}\right)$ emissions, hitherto not implemented in cement industry, is the combustion of fuels in oxygen-enriched air (zero-emission oxy-fuel combustion). It is assumed that implementation of oxy-fuel technology would allow to reduce the $\mathrm{CO}_{2}$ emission by ca. $4 \%$. To date, the technology can't make its way to being applied in cement industry as well as in power production mainly due to the protection of oxygen and the costs thereof.

As shown in the aforementioned assessment of the possibilities to reduce $\mathrm{CO}_{2}$ emission in clinker sintering processed, virtually all reserves have already been used up. Therefore, further reduction in emissions must be sought for outside the sintering process.

A method that allows to achieve significant indirect reduction in $\mathrm{CO}_{2}$ emission consists in the reducing the quantities of clinker used in the cement and replacing it by additives with hydraulic properties such as blast furnace slag, fly ash from power plants, silica dust or limestone. New cement standards permit the use of various cement additives. The Table 2 presents examples of the effects of cement additives on the reduction in the emission of carbon dioxide from cement production processes [7].

\begin{tabular}{|l|l|l|l|}
\hline \multicolumn{1}{|c|}{ Cement type } & \multicolumn{1}{|c|}{$\begin{array}{c}\text { Emission } \\
{[\mathrm{kg} \mathrm{CO} / \mathrm{kg} \mathrm{cem} .]}\end{array}$} & $\begin{array}{c}\text { Additive percentage } \\
\text { share [\%] }\end{array}$ & $\begin{array}{c}\mathrm{CO}_{2} \text { reduction } \\
\text { degree in [\%] }\end{array}$ \\
\hline CEM I 32.5 & 0.81 & 0 & 0 \\
\hline CEM III/A 32.5 & 0.52 & 45 & 35 \\
\hline CEM II/A-V 32.5 & 0.6 & 20 & 25 \\
\hline
\end{tabular}

Table 2. The effects of cement additives on the reduction of $\mathrm{CO}_{2}$ emission

A novel method to reduce the energy intensity and the $\mathrm{CO}_{2}$ emissions from cement production process, hitherto not implemented in Poland, is the production of hydraulic binders from mineral waste materials. One of such methods consists in a production of clinker substitute (belite) with a lower lime saturation factor, characterized by lower sintering temperature of ca. $1200^{\circ} \mathrm{C}$, and the resulting lower emission of $\mathrm{CO}_{2}$. The Fig. 5 presents a diagram of such technology (referred to as K-Tech) based on low-carbonate materials and waste fuels.

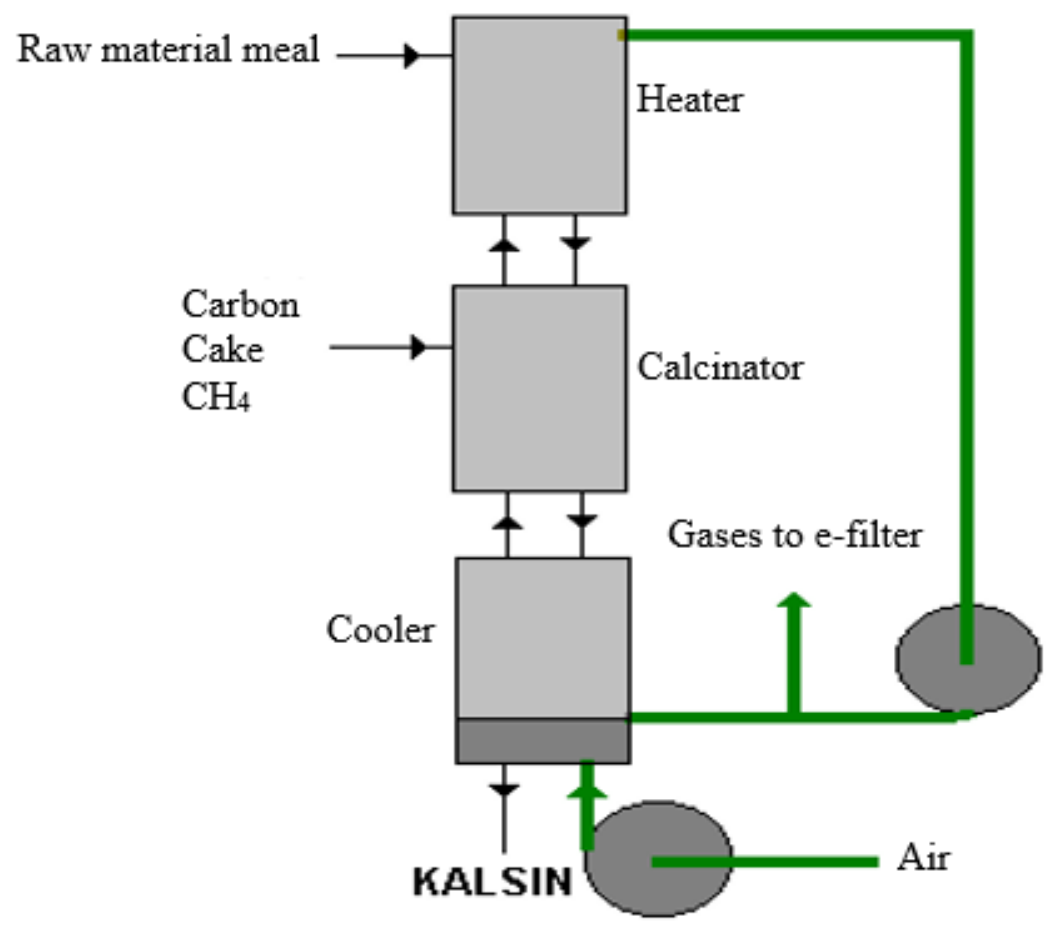

Fig. 5. The diagram of the K-Tech system 
The sinter produced in the process (known as Kalsin) is a replacement (in the amounts of up to 50\%) of conventional clinker. When used in cement, it facilitates the reduction of its energy intensity by ca. along with a significant reduction in $\mathrm{CO}_{2}$ emission compared to conventional cement with the same properties. Compared to conventional cement characterized by the emission level of ca $0.85 \mathrm{~kg} \mathrm{CO}_{2} / \mathrm{kg} \mathrm{cl}$., the emission of cement prepared with the addition of Kalsin is about $0.3 \mathrm{~kg} \mathrm{CO} / \mathrm{kg} \mathrm{cl}$. [2]. K-Tech is one of the new promising technologies for the production of binding materials that meets the requirements of the $3 \times 20$ initiative as well as the future limits of greenhouse gas emissions.

Research is also conducted on the modification of the geometry of the cyclone systems used in the cement industry. Cyclones are among the most popular mechanical dust separators used to separate solid particles from carrier gas in industrial processes. They are used for air pollution control and for conducting technological processes. The main parameters determining their performance is a constant separation efficiency and pressure drop [8].

Another indirect method for the reduction of $\mathrm{CO}_{2}$ emission, already used in the cement industry and continuing to grow rapidly, is the production of electricity in waste heat recovery (WHR) systems. Electricity produced in these systems by means of utilization of waste enthalpy from technological processes is not burdened by any emission; it is the so-called "clean" (zero-emission) energy. Therefore, every kilowatt hour of electricity produced in the WHR systems indirectly reduces the emission (ca. $0.8 \mathrm{~kg} \mathrm{CO}_{2} / \mathrm{kWh}$ ) that would otherwise be generated in production of the same amount of energy in a conventional combustion plant.

In cement mills, electricity may be generated from the rotary kiln waste heat by the following methods:

- the classical steam cycle (Clausius-Rankine cycle);

- the organic Rankine cycle (ORC);

- the Kalina cycle.

Modern WHR systems used in cement industry provide as much as $30 \%$ of the total electricity demand of cement mills. The Fig. 6 presents the values of electric power that can be generated in WHR systems and the resulting reductions in $\mathrm{CO}_{2}$, emission depending on kiln efficiency and the moisture content of materials.

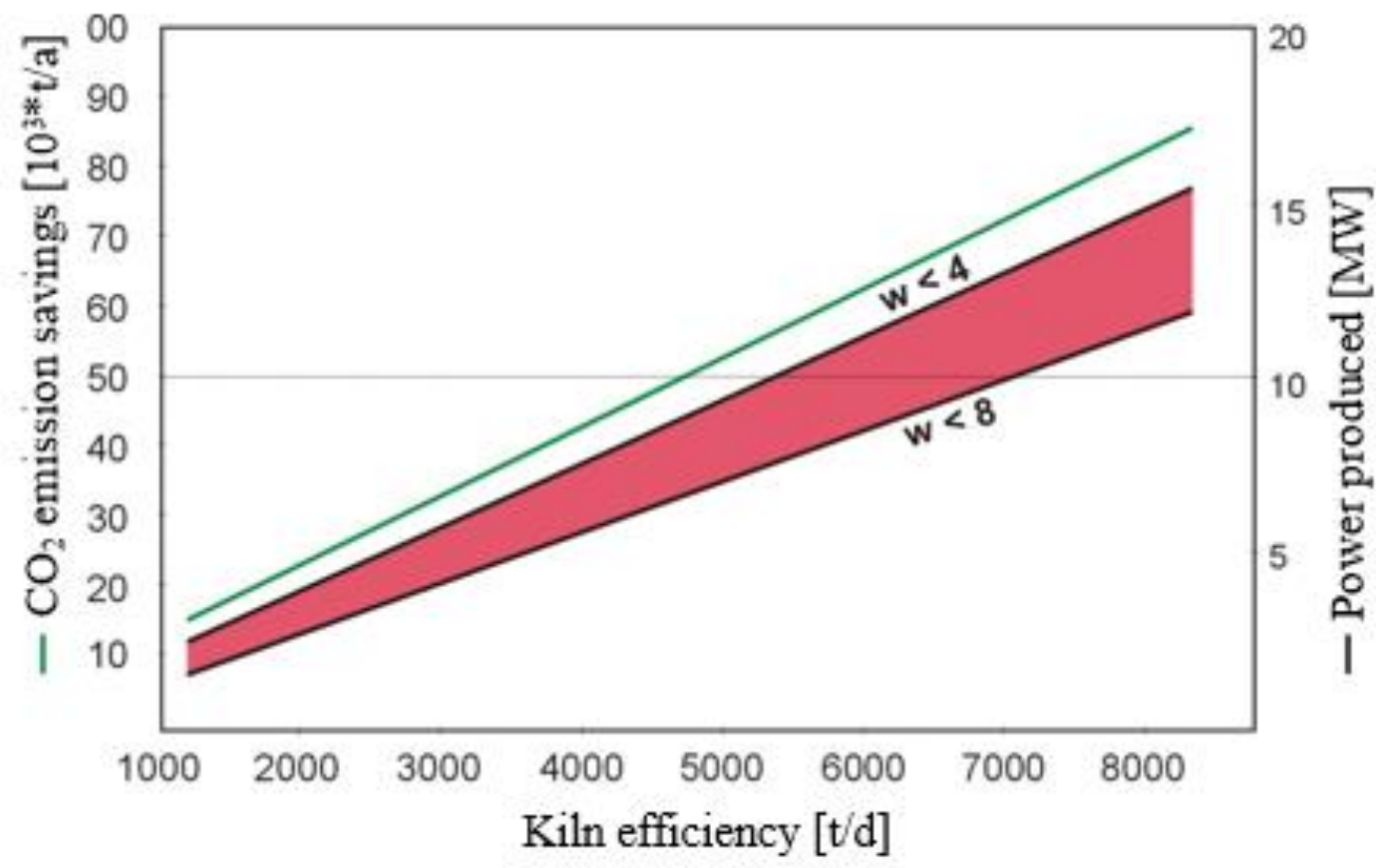

Fig. 6. The electric power as a function of kiln efficiency and materials' moisture content

The mean energy recovery from WHR systems in cement mills is about $32-45 \mathrm{kWh} / \mathrm{ton}$. Therefore, in Polish conditions cement mills would be capable of producing $4-16 \mathrm{MW}$ of clean energy and thus indirectly reducing $\mathrm{CO}_{2}$ emissions by 10,000 to $70,000 \mathrm{Mg} \mathrm{CO}_{2}$ /year [7].

No WHR systems have been installed in Polish cement mills to date. WHR systems may be a rescue solution for cement mills when all other means to reduce the greenhouse gas emissions are used up. Because of progressive increase in electricity prices usually based systems Rankine cycle are used in heat power engineering [9]. 


\section{New technologies for $\mathrm{CO}_{2}$ reduction}

As demonstrated by the methods for the reduction of $\mathrm{CO}_{2}$ emission and the related efficacy data presented above, the problem of $\mathrm{CO}_{2}$ emission in cement production remains unsolved. The effects of the reduction measures are insufficient to meet the 3x20 initiative's limits of permissible emission of greenhouse gases. The situation is even worse when new $\mathrm{CO}_{2}$ emission levels proposed by the European Commission to be in force from the year 2020 are considered. The current deficit of $\mathrm{CO}_{2}$ emission, destined to increase significantly after new limits are introduced in 2020, may result in the need to reduce the production down to the allocated $\mathrm{CO}_{2}$ emission levels or to purchase emission permits. Further economic development and the expansion of road infrastructure and residential areas in Poland will require the production to be increased rather than reduced. Also, the option of purchasing the remaining $\mathrm{CO}_{2}$ emission is infeasible as it would lead to an increase in the price of cement produced in Poland and to possible imports of cheaper cement from another country. Therefore, other method must be sought by the industry to reduce $\mathrm{CO}_{2}$ emission. The solutions should also take into account the future scenarios regarding emission reductions coming into force after the year 2030. The Blue Map scenario assumes that the emission required to produce 1 ton of cement would be reduced from the current value of $680 \mathrm{~kg} \mathrm{CO} / \mathrm{Mg}$ cem. to $406 \mathrm{~kg} \mathrm{CO}_{2} / \mathrm{Mg}$ cem (the minimum variant) or even down to $338 \mathrm{~kg} \mathrm{CO}_{2} / \mathrm{Mg}$ cem. (the optimistic variant). At current state of the art and with carbon being used as the technological fuel, such reduction of greenhouse gases could be obtained by implementation of carbon capture and storage (CCS) systems (pursuant to the Directive 2009/31/EC of the European Parliament and of the Council on the geological storage of carbon dioxide. However, this method is not only expensive in terms of the required investment and maintenance costs, but it would also cause significant logistical problems [10].

Due to the current threats for conventional cement production technologies resulting from the carbon dioxide emission reduction requirements, the search continues for new binders characterized by properties similar to those of cement with lower energy intensity and $\mathrm{CO}_{2}$ emissions. Examples of such studies include the development of a novel binder referred to as geopolymer cement. The name, originating from a mineral polymer formed in geochemical processes, was introduced in 1978 by prof. Josef Davidovits [11]. Geopolymer cement is characterized by energy intensity that is 2-3 times lower and $\mathrm{CO}_{2}$ emission that is over 4 times lower than that of the conventional cement. Due to this fact, it was nicknamed the "green cement". Despite its ecological as well as quality-related advantages, geopolymer cement has not found wider use to date.

Similar characteristics are presented by another green cement, known as Celitement, which was developed at the Karlsruhe Institute of Technology in Germany. Similarly to geopolymer cement, Celitement is characterized by high strength parameters, energy intensity being nearly half of that of conventional concrete, as well as significantly (ca. $50 \%$ ) lower $\mathrm{CO}_{2}$ emissions. These are the technologies of the future which require further research and thus may not yet be considered valid methods for the reduction of $\mathrm{CO}_{2}$ emissions [12].

\section{Conclusion}

Due to the high-temperature process of clinker sintering and to the emission of $\mathrm{CO}_{2}$ due to decarbonation of raw materials, cement production is a high environmental impact process that emits large quantities of greenhouse gases. The ever-stricter limits for acceptable GHG emission require that novel production methods that would allow to meed these limits are being sought for. In relation to the new, significant reduction of $\mathrm{CO}_{2}$ emissions $(40 \%)$ scheduled after the year 2020, the cement industry must search for the ways to reduce these emissions. New technologies and equipment implemented in recent years in the industry and meeting the recent BREF requirements of 2013 exhaust the technological possibilities to reduce $\mathrm{CO}_{2}$ emissions. Further reduction in emissions must be achieved outside the sintering process. A large chance for reducing the acceptable reduction limits in cement mills consists in the production of clean energy in WHR systems based on waste heat generated in the clinker sintering process. Considering the continued increase in worldwide cement production and the resulting increase in carbon dioxide emission as well as the already limited technological possibilities to reduce the emission, the only efficient solution available at the current state of art would consist, similar as in the energy production sector, is implementation of CSS technologies. The authors hope that the effective implementation of mentioned above technologies in the cement industry will lead to the reduction of $\mathrm{CO}_{2}$ emissions and thereby improve the efficiency of the manufacturing process of cement.

\section{References}

[1] The Report „Poland to the Convention on Climate Change” (in Polish: Raport „Polska wobec postanowień Konwencji Klimatycznej), Instytut na rzecz Ekorozwoju, December 2000.

[2] Duda, J. (2004). Energy-saving and environment-friendly technology for cement clinker burning (in Polish: Energooszczędne i proekologiczne techniki wypalania klinkieru cementowego), IMMB Papers (in Polish: Prace IMMB), Opole. 
[3] BREF 2013, Cement - Lime and Magnesium Oxide Manufacturing Industries, May 2013, European Commission, www.cembureau.be.

[4] Polish Minister of Environment of 12 September 2008 on the method of monitoring the size of emissions covered by the EU system of emissions trading (in Polish: Rozporządzenie Ministra Środowiska z dnia 12 września 2008 r. w sprawie sposobu monitorowania wielkości emisji substancji objętych wspólnotowym systemem handlu uprawnieniami do emisji, Dz. U. Nr 183/2008 poz. 1142).

[5] Duczkowska, A. \& Duda, J. (2014). Municipal and industrial waste as alternative raw materials and fuels in the cement production process (in Polish: Odpady komunalne i przemysłowe alternatywnymi surowcami i paliwami w procesie produkcji cementu), ICiMB Papers (in Polish: Prace ICiMB), No. 18, 2014, pp.172-187.

[6] Jõgi, G.; Bashkite, V. \& Karaulova, T. (2010). Analysis of first waste-to-energy plant production line at Kunda Nordic Cement AS, Proceedings of 7th International Conference of DAAAM Baltic Industrial Engineering: 7th International Conference of DAAAM Baltic Industrial Engineering, Tallinn, 22-24 April 2010. Küttner, R. (Ed.), Tallinn University of Technology Press, pp. 358-363.

[7] Tomasiak, J. \& Duda, J. (2015). The impact of innovative techniques WHR to improve the energy efficiency of technological processes (in Polish: Wpływ innowacyjnych technik WHR na poprawę efektywności energetycznej procesów technologicznych), In: Innovations in Management and Production Engineering (in Polish: Innowacje w zarządzaniu i inżynierii produkcji), Knosala, R. (Ed.), Polish Association for Production Management, Opole, 2015, pp. 510-519.

[8] Wasilewski, M. \& Duda, J. (2016). Multicriteria optimisation of first-stage cyclones in the clinker burning system by means of numerical modelling and experimental research, ELSEVIER, Powder Technology, Vol. 289, February 2016, pp. 143-158.

[9] Apostol, V.; Pop, H.; Dobrovicescu, A.; Tudor Prisecaru, T; Alexandru, A. \& Prisecaru, M. (2015). Thermodynamic Analysis of ORC Configurations Used For WHR from a Turbocharged diesel engine, 25th DAAAM International Symposium on Intelligent Manufacturing and Automation, ELSEVIER, Procedia Engineering, Vol. 100, 2015, pp. 549-558.

[10] Duda, J; Kolosowski, M. \& Tomasiak, J. (2015). CCS technology in the cement plant (in Polish: Technologia CCS w zakładzie cementowym), Logistics (in Polish: Logistyka), No. 3, 2015, pp. 1040-1050.

[11] Stemmermann, P.; Schweike, U.; Garberr, K. \& Beuchle G. (2010). Celitement - a sustainable prospect for the cement industry, Cement International, No. 5, 2010, pp.53-65.

[12] Król, M. \& Błaszczyński, T. (2013). Geopolymers in construction (in Polish: Geopolimery w budownictwie), Insulations (in Polish: Izolacje), No. 5, 2013, pp. 38-44. 